\title{
Consumption event of the Pallas's mastiff bat (Molossus molossus) by the Central America bark scorpion (Centruroides exilimanus) in Honduras
}

\author{
Evento de consumo del murciélago mastín de Pallas (Molossus \\ molossus) por el escorpión de corteza de Centroamérica \\ (Centruroides exilimanus) en Honduras
}

\author{
Mario R. EspinaL' ' Lucía I. López², And José M. Mora ${ }^{3 *}$ \\ 'Centro Zamorano de Biodiversidad, Escuela Agrícola Panamericana. San Antonio de Oriente, Francisco Morazán, C. P. 93. Tegu- \\ cigalpa, Honduras. E-mail: mknorops@yahoo.com (MRE). \\ ${ }^{2}$ Unidad de Ciencias Básicas y Carrera de Tecnología de Alimentos, Sede Atenas, Universidad Técnica Nacional. Km 34, Ruta 27, C.

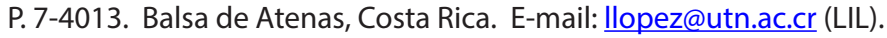 \\ ${ }^{3}$ Unidad de Ciencias Básicas, Sede Atenas y Carrera de Gestión Ecoturística, Sede Central, Universidad Técnica Nacional. Villa \\ Bonita de Alajuela, $50 \mathrm{~m}$ S de Molinos de Costa Rica (carretera a Villa Bonita), A. P. 1902-4050. Alajuela, Costa Rica. E-mail: \\ josemora07@gmail.com (JMM). \\ *Corresponding author
}

\begin{abstract}
Many arthropods including scorpions are carnivores, but the feeding habits of many species are unknown. However, it is known they feed primarily on other arthropods and also include annelids and small vertebrates. As such several scorpions are potential mammal predators, but there is not any report on scorpions feeding on bats. Our objective is to report a feeding event on a Pallas's mastiff bat (Molossus molossus) by the Central America bark scorpion (Centruroides exilimanus) in southern Honduras. In order to document this event, we took photographs of the specimens, and the time the event occurred. There are several buildings and offices at the Clavo Rico mine in El Corpus, Choluteca, Honduras where we have observed three bat colonies. The habitat in this area corresponds to subtropical moist forest. On 20 October 2015 at $11: 42 \mathrm{~h}$ we found a Central America bark scorpion pulling a female M. molossus from the ceiling of a building. The scorpion probably found or captured the bat inside the ceiling, and it already had eaten parts of the bat's head when we found it. Once on the floor the scorpion dragged the bat underneath of the building's floor. Scorpions are able to predate on vertebrates, although we did not observe the predation event, there are neither reports on bat necrophagy by scorpions and there are no known cases of bat predation by these arthropods. Molossid bats perch in big groups even in sites where scorpions can easily access. A mastiff bat predated in Honduras was much heavier than the bark scorpion that captured it, so if it is a predation event it shows the extraordinary predatory capabilities of an arthropod with a potent venom.
\end{abstract}

Key words: Arachnids; arthropods; Buthidae; diet; moist forest; tropical habitats.

Muchos artrópodos, incluidos los escorpiones, son carnívoros, pero se desconocen los hábitos alimentarios de muchas especies. Se sabe que se alimentan principalmente de artrópodos e incluyen también anélidos y pequeños vertebrados. Potencialmente varias especies de escorpiones son depredadores de mamíferos, pero no hay ningún informe de consumo de murciélagos por escorpiones. Nuestro objetivo es reportar un evento de alimentación de un murciélago mastín de Pallas (Molossus molossus) por el escorpión de corteza de Centroamérica (Centruroides exilimanus) en el sur de Honduras. Para documentar este evento, tomamos fotografías de los especímenes y la hora en que ocurrió el evento. Hay varios edificios y oficinas en la mina Clavo Rico en El Corpus, Choluteca, Honduras donde hemos observado tres colonias de murciélagos. Esta mina está ubicada en el bosque húmedo tropical. El 20 de octubre de 2015 a las 11:42 h, encontramos un escorpión que arrastraba un $M$. molossus desde el techo de un edificio. El escorpión probablemente encontró o capturó al murciélago dentro del techo, y ya se había comido partes de la cabeza cuando lo encontramos. Una vez en el suelo, el escorpión arrastró al murciélago debajo del piso del edificio. Los escorpiones pueden depredar vertebrados, aunque no se observó el proceso de depredación tampoco han sido reportados casos de consumo de murciélagos muertos por escorpiones y no se conocen casos de depredación de murciélagos por estos artrópodos. Los murciélagos molósidos descansan en grandes grupos incluso en sitios donde los escorpiones pueden acceder fácilmente. El murciélago era mucho más pesado que el escorpión, por lo que, si este es un evento de depredación, demuestra las extraordinarias capacidades de un artrópodo con un potente veneno.

Palabras clave: Arácnidos; artrópodos; bosque húmedo; Buthidae; dieta; hábitats tropicales.

C 2020 Asociación Mexicana de Mastozoología, www.mastozoologiamexicana.org

Neotropical region is characterized by a high species diversity and a wide variety of ecological interactions (Brown 2014). This large diversity of species represents various trophic levels both as predators and prey (Freestone et al. 2011). Predation is recognized as the most important cause of mortality in natural populations impacting all life stages (Zug et al. 2001). Predator-prey interactions are one of the main drivers of natural selection, ecological structuring of communities, and the functioning of ecosystems (Portalier et al. 2019; Valdez 2020). 
Arthropods are the most diverse group in tropical habitats, and they are fundamentals to functioning of ecosystem and maintenance of biodiversity (Kremen et al. 1993). Many vertebrates (e. g., lizards, birds, and bats) depend on arthropods for their survival (Mooney et al. 2010), and viceversa, many arthropods are carnivores, especially arachnids and scorpions (Wise 1993; Valdez 2020). Scorpions are both predators and prey of other organisms that form trophic webs (Valdez 2020). Information about food habits of scorpions are scarce and scattered throughout the literature (Barro and Cherva 2013). They feed primarily on other arthropods but include annelids and small vertebrates (McCormick and Polis 1990). Species of the family Buthidae have especially potent venom and include other scorpions, spiders, centipedes, chilopods, and insects in their diet (Koch 1977; McCormick and Polis 1990), and are also a human health concern (Borges et al. 2012).

A majority of terrestrial arthropods are primarily carnivorous, and those that are venomous tend to feed on larger prey than the non-venomous species (Molinari et al. 2005). Examples of predatory arthropods are praying mantises, wasps, mygalomorph spiders, scorpions, solpugids, decapod crustaceans, and scolopendrid centipedes (McCormick and Polis 1990; Molinari et al. 2005). While although all of these are potential bat predators (Molinari et al. 2005), there have been no previous reports of bat predation and consumption by scorpions. The Central America bark scorpion (Centruroides exilimanus Teruel and Stockwell, 2002, Scorpiones: Buthidae) is one of nine scorpion species known for Honduras (Teruel and Stockwell 2002).

Pallas's mastiff bat (Molossus molossus Pallas 1766 Molossidae) roosts in hollow trees, coconut palms, mines and buildings (Mora et al. 2018). It is a common "house bat" that roosts in building ceilings and roofs in large colonies (Barros 2014). Specific predators of this species are unknown in Honduras (Mora et al. 2018). However, several bird species are known predators of $M$. molossus through its distribution range: black-and-white owl (Ciccaba nigrolineata), merlin (Falco columbaris), peregrine falcon (Falco peregrinus), and great kiskadee (Pitangus sulphuratis; Loureiro and $\operatorname{Lim} 2019$ ). Here, we report a case of C. exilimanus feeding on M. molossus in southern Honduras.

We observed what appears to have been predation of M. molossus by C. exilimanus. We photographed the event as it occurred. The identification of the scorpion was determined based on Teruel and Stockwell (2002), and subsequently confirmed by R. Teruel (pers. comm.). The bat identification was based on Mora (2016). Our observations were at the Clavo Rico mine in the Municipality El Corpus, Department of Choluteca in southern Honduras $\left(13^{\circ} 17^{\prime} 19^{\prime \prime} \mathrm{N}, 87^{\circ} 01^{\prime} 47^{\prime \prime} \mathrm{W}\right.$; Figure 1). There are several buildings and administration offices at this mine. There are known molossid colonies in three of the buildings, as well as abandoned tunnels in the mine used as bat roosts (M. Espinal, pers. obs.). El Corpus is at an elevation range between the lowland coastal plain of tropical dry forest life zone and the pine-covered highlands (Zerbock 2005). It is located $17 \mathrm{~km}$ east of the city of Choluteca at an elevation of $390 \mathrm{~m}$ (Zerbock 2005). The whole municipality is very mountainous with elevations ranging from $80 \mathrm{~m}$ where the foothills meet the Choluteca valley, to over $1,000 \mathrm{~m}$ at the eastern section at the limit with the municipality of San Marcos de Colón (Zerbock 2005). The vegetation is tropical moist forest influenced by the tropical dry forest with several deciduous tree species (Mayorga 1989; COHDEFOR 1994). The area is somewhat cooler than the lowlands reflecting the topography with an average annual temperature of $25.5^{\circ} \mathrm{C}$, that reaches $28^{\circ} \mathrm{C}$ in March (Mayorga 1989).

On 20 October 2015 at 11:42 h, we observed a scorpion C. exilimanus pulling a female bat $M$. molossus from the ceiling of a building at the Clavo Rico mine. The scorpion was observed as it was emerging from the ceiling of an office and moving down the wall (Figure 2). We assume that the scorpion found or captured the bat inside the ceiling space where there is a colony of M. molossus. When we approached the scorpion, it moved down the wall until it reached the floor, but never released the bat holding it with the chelicerae. Neither our presence nor the camera light or sounds disturbed the scorpion. When we attempted to grab the bat, the scorpion did not release it and continued moving. When discovered, the scorpion had already eaten parts of the bat's head. After emerging from ceiling, the bat was on the scorpion's back as it carried it down the wall to the floor then proceeded to drag the bat in the floor, where we captured it for identification.

As we did not witness the initial encounter between the scorpion and the bat, we were unable to verify if this was predation or scavenging. However, the dead bat was fresh and soft and we surmised it had been recently killed (Figure 2). It did was not dry or stiff nor have any odor of decay. When we attempted to grab the bat, the scorpion did not release it suggesting that it perceived the movement as the struggling of its prey. This suggested that the scorpion had recently killed the bat and did not want to lose its prey.

This is the first record a scorpion eating a bat. Although scorpions are predators, their relationship with vertebrates is generally as prey despite being venomous (Polis et al. 1981; Valdez 2020). Two bat species, Otonycteris hemprichii and Antrozous pallidus, are known to prey on scorpions. Up to $70 \%$ of the feces of $O$. hemprichii contained scorpion fragments (Holderied et al. 2011) and A. pallidus includes scorpions in its diet and is resistant to the venom of $C$. sculpturatus (Hopp et al. 2017). However, there are many records of terrestrial arthropods that prey on vertebrates (Valdez 2020). These include insects, spiders and scorpions that feed on small lizards (Blondheim and Werner 1989; Jehle et al. 1996; Pérez et al. 2010; Pérez and Minoli 2014). Scalloped centipedes prey on anurans, small lizards, small birds, mice and bats (Molinari et al. 2005; Martínez-Coronel et al. 2019; Valdez 2020). 


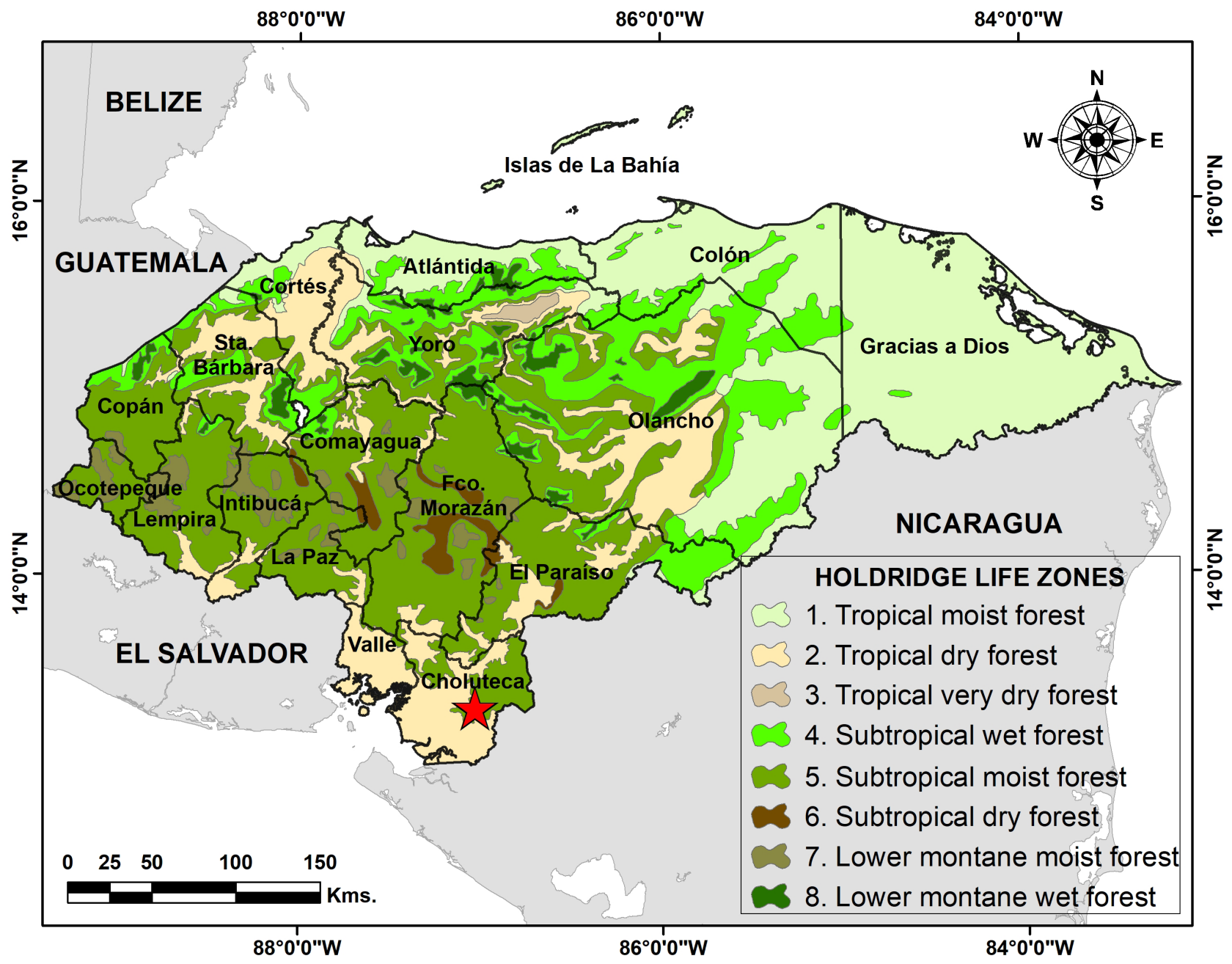

Figure 1. Distribution of life zones in Honduras according to the Holdridge classification system. The red star indicates the location of the Clavo Rico mine, El Corpus, Choluteca, southern Honduras.

The most common mammals predated by arthropods are bats and rodents, mainly spiders and centipedes ( $\underline{\text { Val- }}$ dez 2020). The most prominent predators of bats in general are owls, hawks, and snakes (Nyffeler and Knörnschild 2013). Predators of Pallas's mastiff bat include owls, falcons and the great kiskadee (Loureiro and Lim 2019). However, few large arthropods are also occasional bat predators (Molinari et al. 2005; Altringham 2011; Nyffeler and Knörnschild 2013) or take advantage of carcasses (Prous et al. 2017). The centipede Scolopendra gigantean was observed killing and eating individuals of three species of bats: Mormoops megalophylla, Pteronotus davyi (Mormoopidae) and Leptonycteris curasoae (Phyllostomidae) in a cave in Venezuela (Molinari et al. 2005). Scolopendra viridicornis predated to Eptesicus furinalis (Vespertilionidae) in a cave in Reserva Natural Vale, Espirito Santo, Brazil (Srbek-Araujo et al. 2012), and M. molossus in Cristalino State Park, Mato Grosso, Brazil (Noronha et al. 2015). Scolopendra sumichrasti was observed predating on Natalus mexicanus (Natalidae; Martínez-Coronel et al. 2019).

The most common arthropods that prey on bats are spiders with reports from almost every continent, especially from the Neotropics (Nyffeler and Knörnschild 2013). Spi- ders use sticky webs that opportunistically capture bats (Nyffeler and Vetter 2018). There is little information on other predators, particularly in the tropics where bats and their predators are most diverse. Scorpions have venomous stingers and a foraging strategy that enables them to be predators of small mammals that are encountered in their forest environments (Valdez 2020). Up to $10 \%$ of scorpion diets are snakes (Greene 1997) which they are able to subdue with neurotoxins (Valdez 2020).

Prior to this report there have been no previous reports of scorpions preying on bats. It is possible that bat predation by scorpions may be more frequent than thought, especially on molossid bats which roost in large colonies that include building roofs where scorpions would have ready access (Mora et al. 2018; Loureiro and Lim 2019). Venomous arthropods capture larger prey than non-venomous ones (McCormick and Polis 1982). Therefore, the more venomous the arthropod the larger the prey it should be able to catch. In this case the mastiff bat was considerably larger than the bark scorpion that apparently captured it. This suggests that venomous arthropods have greater range of potential prey. Predation on vertebrates by arthropods is uncommon in ecological studies, as it is not frequently 


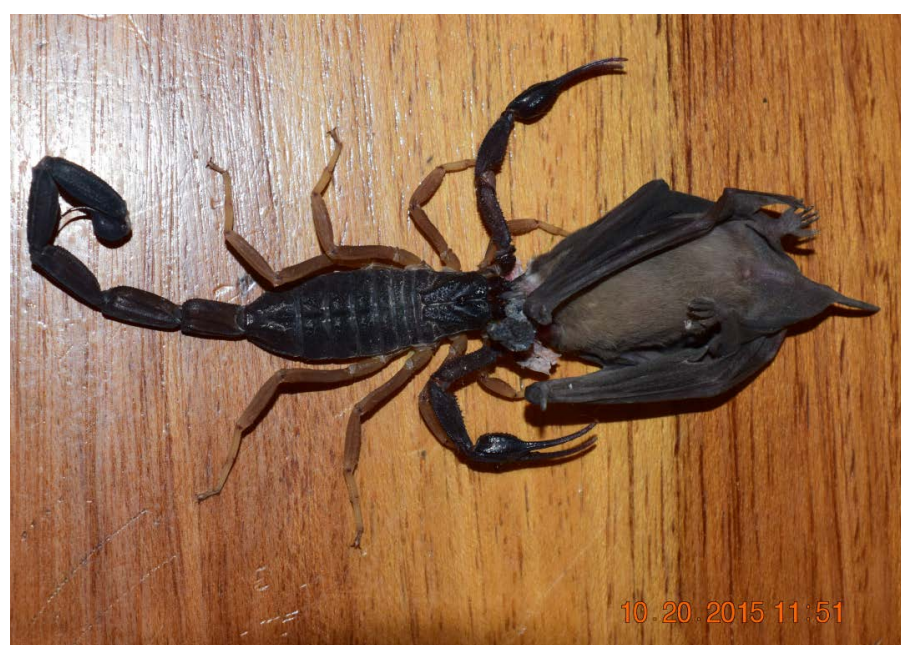

Figure 2. A Central America bark scorpion (Centruroides exilimanus) going out from the ceiling of an office with a female Pallas's mastiff bat (Molossus molossus) at the Clavo Rico mine, El Corpus, Choluteca, Honduras.

observed and considered as rare events (Valdez 2020). Recognizing and quantifying such predator-prey interactions will further identify patterns and potential impacts of such relationships and how it may shape vertebrate populations and communities (Valdez 2020).

\section{Acknowledgements}

We thank G. Flores for alert us on this event, and J. M. PechCanche and two anonymous referees for their comments and suggestions on the manuscript, and specially to $B$. W. Miller and C. Cornejo-Latorre for language corrections and great content input. A special acknowledgement to R. Teruel for the identification of the scorpion species and his kind responses. JMM and LIL acknowledge D. Tobias of the Unidad de Ciencias Básicas, UTN Atenas, for assigning time to work in this report.

\section{Literature cited}

Altringham, J. D. 2011. Bats, from Evolution to Conservation. Second edition. Oxford University Press. Oxford, England.

Barro, A., and T. Cherva. 2013. Depredación de Scolopendra alternans (Chilopoda: Scolopendromorpha) por Rhopalurus junceus (Scorpiones: Buthidae). Revista Cubana de Ciencias Biológicas 2:77-78.

Barros, M. A. S. 2104. First record of Molossus molossus (Pallas, 1766) (Mammalia: Chiroptera) in the state of Rio Grande do Norte, northeastern Brazil. Check List 10:1520-1524.

Blondheim, S., AND Y. L. Werner. 1989. Lizard predation by the widow spiders Latrodectus pallidus and L. revivensis (Theridiidae). British Herpetological Society Bulletin 30:26-27.

Borges, A., R. J. Miranda, and J. M. Pascale. 2012. Scorpionism in Central America, with special reference to the case of Panama. The Journal of Venomous Animals and Toxins including Tropical Diseases 18:130-143.

Brown, J. H. 2014. Why are there so many species in the tropics? Journal of Biogeography 41:8-22.

Corporación Hondureña de desarrollo Forestal (COHDefor). 1994. Estudio preliminar de la cuenca Guanacaure. CAREIMACHCOHDEFOR. Tegucigalpa, Honduras.
Freestone, A. L., R. W. Osman, G. M. Ruiz, and M. E. Torchin. 2011. Stronger predation in the tropics shapes species richness patterns in marine communities. Ecology 92:983-993.

GREenE, H. W. 1997. Snakes: the evolution of mystery in nature. University of California Press. Berkeley and Los Angeles, California, U.S.A.

Holderied, M., C. Korine, AND T. Moritz. 2011. Hemprich's longeared bat (Otonycteris hemprichii) as a predator of scorpions: whispering echolocation, passive gleaning and prey selection. Journal of Comparative Physiology A 197:425-433.

Hopp, B. H., R. S. Arvidson, M. E. Adams, and K. A. Razak. 2017. Arizona bark scorpion venom resistance in the pallid bat, $A n$ trozous pallidus. PLoS ONE 12:e0183215.

Jehle, R., A. Franz, M. Kapfer, H. Schramm, and H. G. Tunner. 1996. Lizards as prey of arthropods: Praying Mantis religiosa (Linnaeus, 1758) feeds on juvenile sand lizard Lacerta agilis Linnaeus, 1758. Herpetozoa 9:157-159.

KocH, L. E. 1977. The Taxonomy, Geographic Distribution and Evolutionary Radiation of Austral-papuan Scorpions. Record Western Australian Museum 5:83-367.

Kremen, C., R. Colwell, T. L. Erwin, D. D. Murphy, R. F. Noss, and M. A. Sanjayan. 1993. Terrestrial arthropod assemblages: their use in conservation planning. Conservation Biology 7:796-808.

Loureiro, L., AND B. Lim. 2019. Pallas's Mastiff Bat (Molossus molossus). Pp. 626 in Handbook of the mammals of the world. Vol. 9 Bats (Wilson, D. E., and R. A. Mittermeier, eds.). Lynx Ediciones. Barcelona, Spain.

Martínez-Coronel, M., F. G. Cupul-Magaña, and L. F. NietoToscano. 2019. Ataques del ciempiés gigante Scolopendra sumichrasti Saussure, 1860 (Scolopendromorpha: Scolopendridae) sobre el murciélago Natalus mexicanus Miller, 1902 (Chiroptera: Natalidae) en Chiapas, México. Acta Zoológica Mexicana (nueva serie) 35:1-5.

MaYorGA, J. J. 1989. Water quality of low stream flows on the Cerro Guanacaure Watershed, Choluteca, Honduras. Master thesis, University of Arizona. Tucson, U.S.A.

McCormick, S., AND G. A. Polis. 1982. Arthropods that prey on vertebrates. Biological Reviews 57:29-58.

McCormick, S., AND G. A. Polis. 1990. Prey, predators, and parasites. Pp. 294-320 in The Biology of Scorpions (Polis, G. A., ed.). Stanford University Press. Stanford, U.S.A.

Molinari, J., E. E. Gutıérrez, A. A. Ascençăo, J. M. Nassar, A. ArENDS, AND J. R. MÁrQuez. 2005. Predation by giant centipedes, Scolopendra gigantea, on three species of bats in a Venezuelan cave. Caribbean Journal of Science 41:340-346.

Mooney, K. A., D. S. Gruner, N. A. Barber, S. A. Van Bael, S. M. Philpott, ANd R. Greenberg. 2010. Interactions among predators and the cascading effects of vertebrate insectivores on arthropod communities and plants. Proceedings of the National Academy of Sciences of the United States of America 107:7335-7340.

Mora, J. M. 2016. Clave para la identificación de las especies de murciélagos de Honduras. Ceiba 54:93-117.

Mora, J. M., L. I. López, M. Espinal, L. Marineros, and L. Ruedas. 2018. Diversidad y conservación de los murciélagos de Honduras. Master Print S. de R.L. Tegucigalpa, Honduras.

Noronha, J. A., L. D. Battirola, A. Chagas, R. M. Miranda, R. CarPANEDo, AND D. J. Rodrigues. 2015. Predation of bat (Molossus 
molossus: Molossidae) by the centipede Scolopendra viridicornis (Scolopendridae) in Southern Amazonia. Acta Amazonica 45:333-336.

Nyffeler, M., AND M. Knörnschild. 2013. Bat predation by spiders. Plos One 8:e58120.

Nyffeler, M., And R. S. Vetter. 2018. Black widow spiders, Latrodectus spp. (Araneae: Theridiidae), and other spiders feeding on mammals. Journal of Arachnology 46:541-548.

Pérez, C. H. F., L. J. Avila, and A. Camargo. 2010. Predation of Liolaemus huacahuasicus (Squamata: Iguania: Liolaemini) by Brachistosternus intermedius (Scorpiones: Bothriuridae) in cumbres Calchaquies, Tucumán Province, northwestern Argentina. Cuadernos de Herpetología 24:123-124.

Pérez, C. H. F., and I. Minoli. 2014. Depredación de Homonota darwinii Laurent 1984 (Squamata: Phyllodactylidae) por Brothriurus burmeisteri Kraepelin, 1894 (Scorpiones: Bothriuridae) en la provincia del Chubut, Argentina. Cuadernos de Herpetología 28:145-146.

Polis, G. A., W. D. Sissom, AND S. J. McCormick. 1981. Predators of scorpions: field data and a review. Journal of Arid Environments 4:309-326.

Portalier, S. M. J., G. F. Fussmann, M. Loreau, and M. Cherif. 2019. The mechanics of predator-prey interactions: First principles of physics predict predator-prey size ratios. Functional Ecology 33:323-334.

Prous, X., T. Pietrobon, M. S. Ribeiro, and R. D. A. Zampaulo. 2017. Bat necrophagy by a whip-spider (Arachnida, Amblypygi, Phrynidae) in a cave in the eastern Brazilian Amazon. Acta Amazonica 47:365-368.

Srbek-Araujo, A. C., M. R. Nogueira, I. Passos de Lima, and A. L. Peracchi. 2012. Predation by the centipede Scolopendra viridicornis (Scolopendromorpha, Scolopendridae) on roofroosting bats in the Atlantic Forest of southeastern Brazil. Chiroptera Neotropical 18:1128-1131.

Teruel, R., And S. A. Stockwell. 2002. A revision of the scorpion fauna of Honduras, with the description of a new species (Scorpiones: Buthidae, Diplocentridae). Revista Ibérica de Aracnología 6:111-127.

VALDEZ, J. 2020. Arthropods as Vertebrate Predators: A Review of Global Patterns. Global Ecology and Biogeography 29:1691-1703.

WISE, D. H. 1993. Spiders in ecological webs. Cambridge University Press. Cambridge, England.

Zerbock, O. 2005. Land use and water quality in El Corpus, Choluteca, Honduras. Master thesis. Michigan Technological University. Houghton, U.S.A.

Zug, G. R., L. J. Vitt, ANd J. P. Caldwell. 2001. Herpetology. An Introductory Biology of Amphibians and Reptiles. Second Edition, Academic Press. San Diego, U.S.A.

Associated editor: Tamara Rioja-Paradela

Submitted: September 22, 2020; Reviewed: November 26, 2020.

Accepted: November 30, 2020; Published on line: December 8, 2020. 